\section{Reproduction of the threatened Annual Killifish Austrolebias nigrofasciatus (Cyprinodontiformes: Rivulidae), confined in a natural environment}

\author{
M.V. Volcan ${ }^{1}$, A.P. Fonseca ${ }^{2}$ \& R.B. Robaldo ${ }^{3}$ \\ ${ }^{1}$ Instituto Pró-Pampa (IPPampa), Laboratório de Ictiologia. Rua \\ Gomes Carneiro, 1043, bairro centro, Pelotas, Rio Grande do \\ Sul, Brasil. \\ 2 Programa de Pós-Graduação em Aqüicultura, Instituto de \\ Oceanografia, Universidade Federal do Rio Grande (FURG). \\ Avenida Cassino, 2001, Rio Grande, Rio Grande do Sul, Brasil. \\ ${ }^{3}$ Departamento de Fisiologia e Farmacologia, Instituto de \\ Biologia, Universidade Federal de Pelotas (UFPEL). Rua Cinco, \\ 300, Capão do Leão, Rio Grande do Sul, Brasil. \\ Email: ${ }^{1}$ matheusvolcan@hotmail.com (corresponding author), \\ 22alincaf@gmail.com, ${ }^{3}$ ricardo.robaldo@pq.cnpq.br
}

Annual killifishes are found in seasonal wetlands that tend to dry up at certain times of the year (Costa 2002). There are 324 species belonging to the Rivulidae family, and their distribution extends from southern North America through southern South America (Costa 2008). Austrolebias is the second most representative genus of annual fishes, with 34 recorded species (Costa 2008).

Studies have shown that killifishes have elaborate reproductive behavior, mainly associated with the marked sexual dimorphism of the species (Belote \&

Date of publication (online): 26 June 2011

Date of publication (print): 26 June 2011

ISSN 0974-7907 (online) | 0974-7893 (print)

Editor: Neelesh Dahanukar

Manuscript details:

Ms \# 02575

Received 18 September 2010

Final revised received 07 May 2011

Finally accepted 06 June 2011

Citation: Volcan, M.V., A.P. Fonseca \& R.B. Robaldo (2011) Reproduction of the threatened Annual Killifish Austrolebias nigrofasciatus (Cyprinodontiformes: Rivulidae), confined in a natural environment. Journal of Threatened Taxa 3(6): 1864-1867.

Copyright: ( M.V. Volcan, A.P. Fonseca \& R.B. Robaldo 2011. Creative Commons Attribution 3.0 Unported License. JoTT allows unrestricted use of this article in any medium for non-profit purposes, reproduction and distribution by providing adequate credit to the authors and the source of publication

Acknowledgements: The authors wish to express their gratitude to IBAMA/ICMBio for issuing the collection license (15108-1). A.P. Fonseca thanks CAPES/PROAP for the M.Sc grant. R.B. Robaldo (312035/2009-8) is research fellow of Brazilian CNPq.

OPEN ACCESS | FREE DOWNLOAD
Costa 2004; Garcia et al. 2008). However, little is known about their reproduction in their natural environment (Arenzon et al. 1999; Shibatta 2005). In Brazil, the annual fishes are considered one of the most threatened groups of vertebrates (Rosa \& Lima 2008). Regarding the possible strategies for ensuring Rivulidae conservation, several authors stress the importance of conducting studies aimed to improve the knowledge on the biology and ecology of these species (Reis et al. 2003; Rosa \& Lima 2008; Volcan et al. 2010).

Reproductive success depends on timing, location and resource availability (Wootton 1990), and data on fish fecundity is important for estimating reproductive potential. Egg size influences the fitness of mothers and offspring (Bernardo 1996), being an important determinants of egg and larval quality that is positively correlated with egg and fry survival and larval growth rate (Gall 1975; Chambers 1997). Large young have among other things wider mouth gape, longer visual reactive distance and greater swimming speed than smaller conspecifics (Blaxter 1986; Miller et al. 1988).

Austrolebias nigrofasciatus Costa \& Cheffe, 2001 (Image 1) is a threatened annual fish, endemic to the waters of São Gonçalo channel, Patos-Mirim lagoon system and their tributaries, in southern Brazil (Reis et al. 2003; Rosa \& Lima 2008; Volcan et al. 2009). The purpose of current investigation was to study the reproduction of $A$. nigrofasciatus confined in small cages in their biotope.

Material and Methods: The study was conducted in a seasonal wetland ( $31^{\circ} 48$ ' 25 "S \& $\left.52^{\circ} 25^{\prime} 11^{\prime \prime} \mathrm{W}\right)$ in an

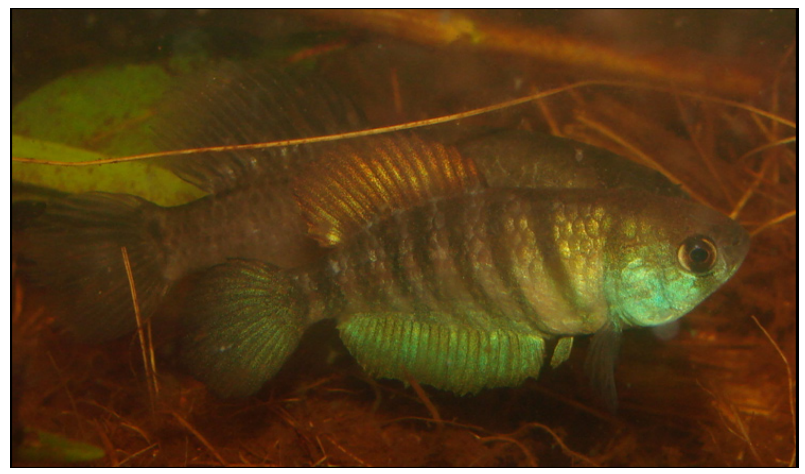

Image 1. Male of Austrolebias nigrofasciatus captured in the floodplains of Padre Doutor Stream, southern Brazil. 


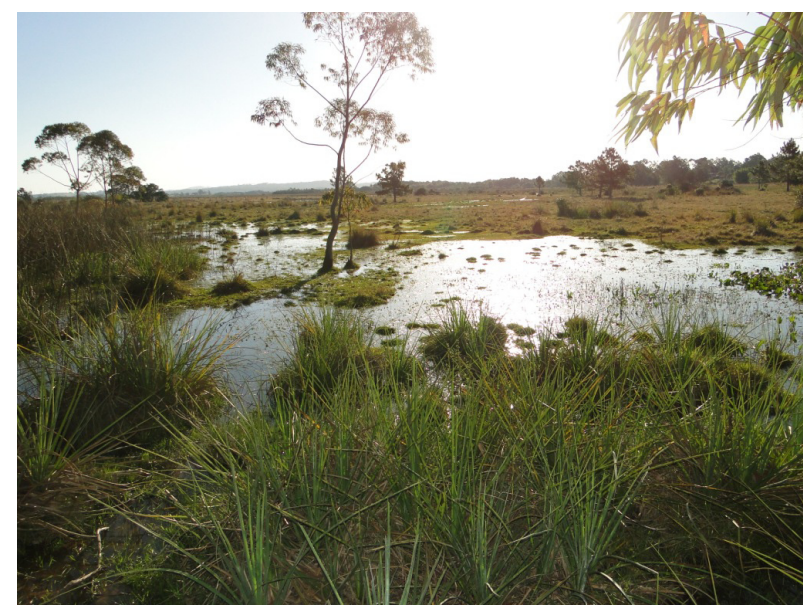

Image 2. Wetland where the experiment was conducted, floodplains of Padre Doutor stream basin, southern Brazil.

area about $5,000 \mathrm{~m}^{2}$, located in the floodplain of Padre Doutor Stream (Patos-Mirim lagoon system) (Image 2). The sampled wetland is a shallow depression (about $30 \mathrm{~cm}$ deep) with great diversity of macrophytes, invertebrates, especially larvae and vertebrates such as amphibians, and Cynopoecilus melanotaenia being the only annual fish species registered to this biotope besides A. nigrofasciatus.

Hand-net (D shaped, 2mm mesh) was used to collect the broodstock. Fishes were captured, measured with a digital caliper (to the nearest of $0.01 \mathrm{~mm}$ ) for total length (TL). Three pairs were captured (males $37.6 \pm 3.8 \mathrm{~mm}$ and females $36.9 \pm 1.5 \mathrm{~mm}$ ) and placed in small $5 \mathrm{~mm}$ mesh net-cages with a volume of six liters. The mesh placed on the cage was used for slipping food into the cage, without allowing the fish to escape.

A spawning nest was placed inside each unit consisting of a transparent plastic pot $(20 \times 15 \times 5 \mathrm{~cm})$ with $40 \mathrm{~g}$ of acrylic yarn as a substrate for spawning. The nests were replaced each week, and the bottom of the cage aspirated to count the eggs. Fecundity was estimated as the total number of eggs produced during the reproductive period and is shown as mean \pm standard deviation (SD). The diameters of all the collected eggs were measured $(0.01 \mathrm{~mm})$ with a stereomicroscope equipped with micrometer scale. The experiment lasted four weeks (06 September to 04 October 2009).

Every three days minimum and maximum temperatures $\left({ }^{\circ} \mathrm{C}\right)$ of the water were recorded. Dissolved oxygen $(0.1 \mathrm{mg} / \mathrm{L}), \mathrm{pH}(0.01)$ and conductivity $(0.1 \mu \mathrm{S} /$ $\mathrm{cm})$ were monitored at the same time intervals.

Results and Discussions: Analysis of water showed that temperature was the abiotic variable with highest fluctuation during the sampling period $\left(9-42{ }^{\circ} \mathrm{C}\right)$, ranging from 11 to $34{ }^{\circ} \mathrm{C}$ in one day. The average $\mathrm{pH}$, dissolved oxygen and conductivity were $6.9 \pm 1.3(6.3-10.5), 5.0 \pm 2.3 \mathrm{mg} / \mathrm{L}(3.4-8.2 \mathrm{mg} / \mathrm{L})$ and $482.0 \pm 50.9 \mu \mathrm{S} / \mathrm{cm}(446-518 \mu \mathrm{S} / \mathrm{cm})$, respectively. This wide variation in thermal and environmental conditions observed in the study, are typical of small seasonal wetlands and were also observed by other authors who studied Austrolebias species in their natural habitat (Errea \& Danulat 2001; Volcan et al. 2011).

A total of 258 eggs were collected in the three experimental units. Average fecundity was $21.5 \pm 12.0$ eggs/female/week (Fig. 1a), with a wide variation over the study period (3-39 eggs/female/week; Fig. 1b).

The average oviposition observed for $A$. nigrofasciatus is within the range found for other
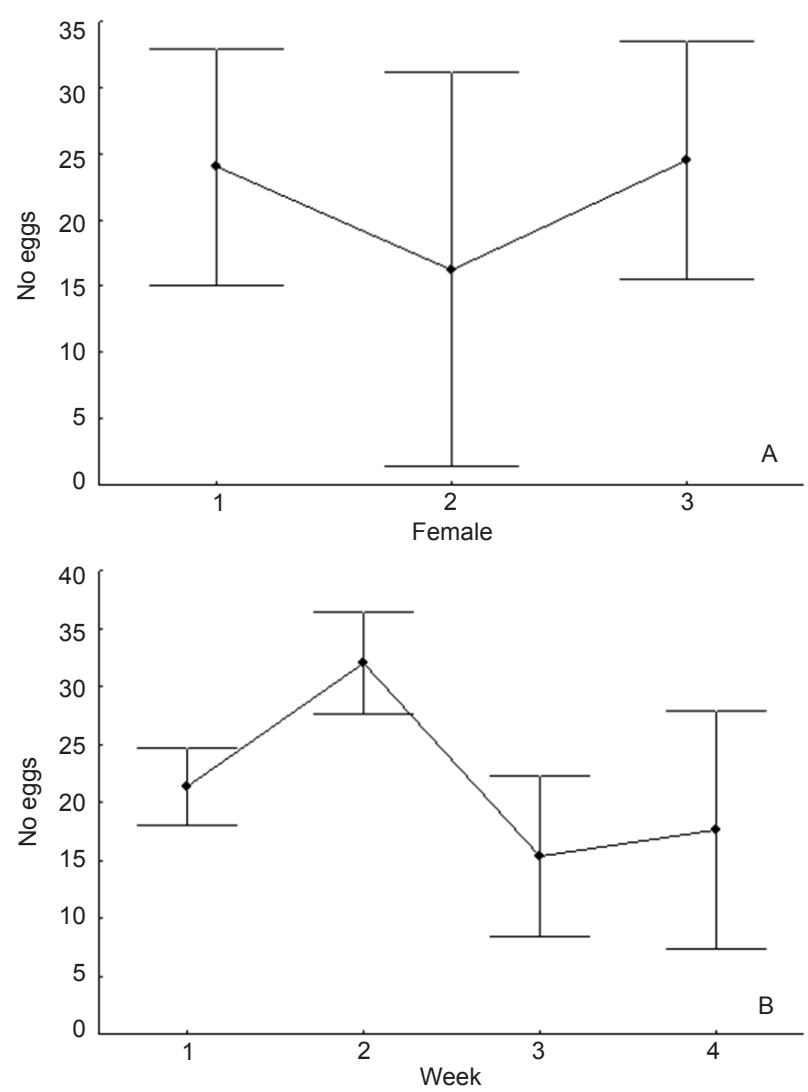

Figure 1. Fecundity mean ( $\pm S D$ ) of each female of Austrolebias nigrofasciatus confined for four weeks in natural environment (A) and mean of weekly fecundity (B). 
Rivulidae. Liu \& Walford (1969) observed a weekly fecundity similar to that observed in the present study for the Austrolebias bellotti with about 21 eggs/female. For Austrolebias toba, Calviño (2005) reported an average weekly fecundity of 57 eggs/ female. For Simpsonichthys boitonei, Shibatta (2005) found an average laying about three eggs/day. However, Volcan (2009) during a reproductive assay of $A$. nigrofasciatus in laboratory conditions observed a fecundity of approximately 30 eggs/week. These values contrast with the present findings where the confined specimens showed approximately $30 \%$ lower fecundity than those kept in laboratory.

The eggs of $A$. nigrofasciatus had spherical shape and a $1.51 \pm 0.12 \mathrm{~mm}$ diameter (Fig. 2a). The egg diameter varied throughout the study period, showing a tendency to reduction from the first week when the average egg diameter was $1.63 \pm 0.10 \mathrm{~mm}$ (Fig. $2 \mathrm{~b}$ ), suggesting to a negative relationship between confinement time and egg diameter. The reduction in
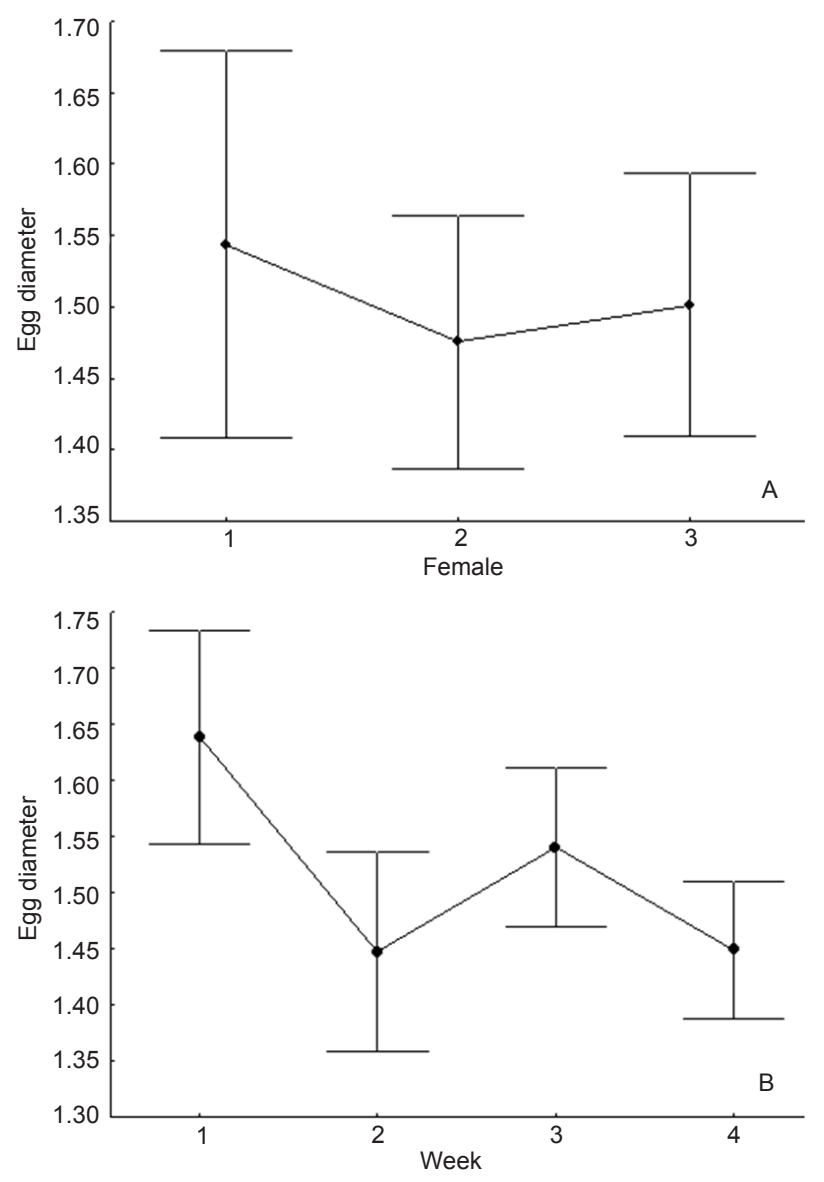

Figure 2. Mean of egg diameter ( $\pm S D$ ) of each female of Austrolebias nigrofasciatus in natural environment (A) and of weekly mean of egg diameter (B) during four weeks. egg diameter during the study period may reflect the negative effect of confinement. Austrolebias males are always courting the females (Belote \& Costa 2004). Garcia et al. (2008) observed an apparent energy loss in Austrolebias reicherti females during the reproduction event. Despite the efforts of the males to secure mating, the females were disinterested. We believe that maintaining the females under conditions of confinement for prolonged periods in the presence of males may end up exerting pressure to produce eggs continuously, making it impossible for the oocytes to reach the optimal size.

According to Costa \& Leal (2009), Leptolebias species have egg diameter ranging from 0.89 to 1.00 $\mathrm{mm}$. For five species of Simpsonichthys, Fava \& Piza (2007) observed that eggs had spherical shape and diameter ranging from 0.89 to $1.11 \mathrm{~mm}$, while for $S$. boitonei an average diameter of $1.60 \mathrm{~mm}$ was observed (Shibatta 2005). For C. melanotaenia, Arenzon et al. (1999) observed oocytes up to $1.37 \mathrm{~mm}$. These studies have corroborated our findings regarding the mean and wide variation in the egg diameter recorded for $A$. nigrofasciatus.

Regardless the reproductive and environmental conditions, we observed that $A$. nigrofasciatus has a high fecundity rate even under confinement conditions, showing that a large number of eggs can be laid in a relatively short period of time. Despite the limitations of this study (especially the small number of samples), these data may help in designing and implementing strategies for the conservation of the species. Based on these results, new approaches and methods should be used to elucidate a clearer reproduction of Austrolebias species in their natural habitat. Knowledge of the biology of annual fishes is an important step to promote the conservation of this endemic and threatened group.

\section{REFERENCES}

Arenzon,A.,A.C.Peret \& M.B.C.Bohrer(1999). Reproduction of the Annual Fish Cynopoecilus maelanotaenia (Regan, 1912) based on a temporary water body population in Rio Grande do Sul State, Brazil. Hydrobiologia 411: 65-70.

Belote, D.F. \& W.J.E.M. Costa (2004). Reproductive behavior patterns in three species of the South American Annual Fish genus Austrolebias Costa, 1998 (Cyprinodontiformes, Rivulidae). Boletim do Museu Nacional do Rio de Janeiro 
514: $1-7$.

Bernardo, J. (1996). The particular maternal effect of propagule size, especially egg size: patterns, models, quality of evidence and interpretation. American Zoologist 36: 216-236.

Blaxter, J.H.S. (1986). Development of sense organs and behavior of teleost larvae with special reference to feeding and predator avoidance. Transactions of the American Fisheries Society 115: 98-114.

Calviño, P. (2005). Austrolebias toba (Cyprinodontiformes: Rivulidae), una especie nueva de pez anual de la Argentina. Revista del Museo Argentino de Ciencias Naturales 7(2): 188-190.

Chambers, R.C. (1997). Environmental influences on egg and propagule sizes in marine fishes, pp. 63-102. In: Chambers, R.C. \& E.A. Trippel (eds). Early Life History and Recruitment in Fish Populations. Chapman and Hall, London, 596pp.

Costa, W.J.E.M.(2002). Peixes anuais brasileiros: diversidade e conservação. Ed. UFPR, Curitiba, Brasil, 238pp.

Costa, W.J.E.M. (2008). Catalog of Aplocheiloid Killifishes of The World - $1^{\text {st }}$ Edition. Rio de Janeiro: Reproarte, 127pp.

Costa, W.J.E.M. \& F. Leal (2009). Egg surface morphology in the Neotropical seasonal killifi sh genus Leptolebias (Teleostei: Aplocheiloidei: Rivulidae). Vertebrate Zoology 59(1): 25-29.

Errea, A. \& E. Danulat (2001). Growth of the Annual Fish, Cynolebias viarius (Cyprinodontiformes), in the natural habitat compared to laboratory conditions. Environmental Biology of Fishes 61: 261-268.

Fava, D. \& T.M. Piza (2007). Egg surface structure in the annual fishes Simpsonichthys (subgenera Ophthalmolebias and Xenurolebias) and Nematolebias (Teleostei: Cyprinodontiformes: Rivulidae): variability and phylogenetic significance. Journal of Fish Biology 71: 889-907.

Gall, G.A.E. (1975). Genetics of reproduction in domesticated rainbow trout. Journal of Animal Science 40: 19-28.

García, D., M. Loureiro \& B. Tassino (2008). Reproductive behavior in the annual fish Austrolebias reicherti Loureiro \& García 2004 (Cyprinodontiformes: Rivulidae). Neotropical Ichthyology 6(2): 243-248.
Liu, R.K. \& R.L. Walford (1969). Laboratory studies on life-span, growth, aging, and pathology of the annual fish Cynolebias bellottii Steindachner. Zoologica 54: 1-16.

Miller, T.J., L.B. Crowder, J.A. Rice \& E.A. Marschall (1988). Larval size and recruitment mechanisms in fishes: toward a conceptual framework. Canadian Journal of Fisheries and Aquatic Science 45: 1657-1670.

Reis, R.E., Z.M. Lucena, C.A.S. Lucena \& L.R. Malabarba (2003). Peixes. In: Fontana, C.S., G.A. Bencke \& R.E. Reis (Orgs). Livro vermelho da fauna ameaçada de extinção no Rio Grande do Sul. Edipucrs, Porto Alegre, Brasil, 632pp.

Rosa, R.S. \& F.C.T. Lima (2008). Peixes, pp. 8-258. In: Machado, A.B.M., G.M. Drummond \& A.P. Paglia (eds.). Livro vermelho da fauna brasileira ameaçada de extinção. Ministério do Meio Ambiente, Brasília.

Shibatta, O. (2005). Reprodução do pirá-brasília, Simpsonichthys boitonei Carvalho (Cyprinodontiformes, Rivulidae), e caracterização de seu habitat na Reserva Ecológica do Instituto Brasileiro de Geografia e Estatística, Brasília, Distrito Federal, Brasil. Revista Brasileira de Zoologia 22(4): 1146-1151.

Volcan, M.V. (2009). Growth and fecundity of annual fish Austrolebias nigrofasciatus (Cyprinodontiformes: Rivulidae) under laboratory conditions. MSc Dissertation, Universidade Federal do Rio Grande, Rio Grande, 59pp.

Volcan, M.V., L.E.K. Lanés \& A.C. Gonçalves (2009). Thereatened fishes of the world: Austrolebias nigrofasciatus Costa and Cheffe, 2001 (Cyprinodontiformes, Rivulidae). Environmental Biology of Fishes 86(4): 443-444.

Volcan, M.V., L.E.K. Lanés \& A.C. Gonçalves (2010). Threatened fishes of the world: Austrolebias univentripinnis Costa \& Cheffe 2005 (Cyprinodontiformes, Rivulidae). Environmental Biology of Fishes 87(4): 319-320.

Volcan, M.V., A.C. Gonçalves \& L.E.K. Lanés (2011). Distribution, habitat and conservation status of two threatened annual fishes (Rivulidae) from southern Brazil. Endangered Species Research 13(2): 79-85.

Wootton, R. (1990). Ecology of Teleost Fishes. Fish and Fisheries. Series 1. New York, Chapman and Hall. 404p.

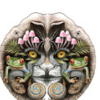

